\title{
Relation between Soil Weed Seedbank and Weed Management Practises and Diversity in Farms in Kisii Central Sub County, Nyanza
}

\author{
*Nyamwamu N. Charles ${ }^{1}$, Karanja Rebecca², Mwangi Peter ${ }^{3}$ \\ ${ }^{1,2,3}$ Department of Botany, Jomo Kenyatta University of Agriculture and Technology, \\ P. O. Box 62000 Nairobi, Kenya \\ anyamwamucharles@gmail.com, brebeccakaranja3@gmail.com, cpnmwangi@fsc.jkuat.ac.ke
}

\section{Keywords: Capparaceae, Abundance, Frequency, Seedbank, Diversity, Smallholder Farmers}

\begin{abstract}
This study sought to determine the relation between soil weed seed bank and weed management practices and diversity in farms in Kisii Central Sub County, Western Kenya. Eight administrative sub-locations were randomly selected. Ten farms were selected at equal distance along transect laid across each sub-location. Weed soil seed bank was assessed from soil samples collected from each of the farms; a sub-sample was taken from a composite sample of ten soil cores of $5 \mathrm{~cm}$ diameter and $15 \mathrm{~cm}$ deep and placed in germination trays in a greenhouse. Weed diversity in soil weed seedbank was calculated using the Shannon index $\left(H^{\prime}\right)$. Twelve weed species from 12 genera of nine families were recorded. Diversity of the weed species in soil weed seed bank was $\left(H^{\prime}=1.48\right)$. Weed management practises significantly affected weed species soil weed seedbank reserves. Use of inefficient and ineffective hand-weeding techniques resulted in high weed species diversity and abundance.
\end{abstract}

\section{Introduction}

Agricultural weeds are plants that compete with crops for moisture, light, space and nutrients $[20,25]$. The conflict between crop productivity and weeds has so far mainly been managed through cultural practices and use of herbicides, but relying solely on chemicals can be unsustainable when weed populations develop resistance to herbicides [19], and because of the environmental impacts of herbicides and their residues. One alternative is the application of current knowledge on the effects of agricultural practices on weed populations to design novel cropping systems of integrated weed management (IWM) that would require few herbicides to manage weeds. IWM combines the use of crop rotation design and adapting cultural practices such as mulching, type of soil tillage and mechanical weeding [2]. IWM relies on weed management principles that have proved to have satisfying efficiency for long-term weed management in organic farming for decades [21].

The weed seed bank is the reserve of viable weed seeds present on the soil surface and scattered in the soil profile and formation of the soil weed seed bank represents an important regeneration components of many weed species [17]. It consists of both new weed seeds recently shed and older seeds that have persisted in the soil for several years. Agricultural soils can contain thousands of weed seeds per square foot and understanding the factors impacting the dynamics of weed seed banks can help in the development of integrated weed management programs [11].

The production of a large number of small seeds is an important survival strategy developed by weeds to survive control methods. According to [12], one plant of Ludwigia octovalvis (Onagraceae) is capable of producing 250,000 seeds. After their dispersal, the seeds might remain on the soil surface or be buried by various biotic and abiotic agents, thus forming a soil seed bank that becomes the primary source of weeds in agro-ecosystems. Weed seed location in the soil seed bank influences germination, emergence and vertical seed distribution in the soil [24].

Weed seed bank studies in situ, that is, the identification and enumeration of weed seedling emergence in the field, might provide a general indication of the composition of the weed flora in the seed bank. However, this method is not precise because seeds from many species can remain viable for long periods but do not germinate because they possess some degree of physical or 
physiological dormancy, while others germinate but do not emerge due to unfavourable environmental conditions. Possible causes in reduction in soil weed seedbank may be explained by various factors like seed and seedling losses in the field due to activities of microorganisms, insects, birds, rodents, lizards and other animals. [10] carried out a study in organic cereal fields in Netherlands and observed that weed seed losses due to predators range between 5-15\%. Similarly, the weed seed losses may be due to occasional periods of soil water stress and germination failure [13]. The dominance of a weed species in the soil weed seed bank is related not only to cultural factors and crop history but also to reproductive capacity of the weed species [18].

However, weed seed bank study; the identification and enumeration of weed seedling emergence from soil samples placed in trays in the greenhouse and irrigated daily for longer periods is more efficient for assessing germination dynamics. It is also possible to assess the potential size of the weed seed bank because many species are capable of extended fluxes of emergence over several weeks under favorable environmental conditions. Under controlled conditions like those in the green house, weed seed germination varies due to dormancy breaking because of greater exposure to sunlight as observed by [4].

There is a need to understand soil weed seed bank germination dynamics and its relationship with observed weed flora on smallholder fields. In ecosystems, weed population is related to the seed bank. The knowledge of seed bank size and of its species composition will contribute to the prediction of infestations and thus leading to improved management strategies for minimizing the effects of the interference of invasive plants with crop growth and yields [29]. The weed seed bank not only serves as a physical history of the past successes and failures of cropping systems, it can also help producers predict the degree to which crop-weed competition will affect crop yield and quality [6].

\section{Materials and Methods}

\subsection{Description of the study area}

Kisii Central Sub County is one of the nine Sub Counties of Kisii County in Southwest Kenya. Temperatures can range from $10^{\circ} \mathrm{C}$ to $30^{\circ} \mathrm{C}$. According to the [15], Kisii Central Sub County (formerly Kisii Central district) had a population of 588,000, but with a population growth rate of $3.6 \%$ the population is now over 700,000 (19\% of whom live in urban areas. It is one of the most densely populated Sub Counties in Kenya and covers an area of $317.4 \mathrm{Km}^{2}$. Due to the high population density, almost all land is put to maximum agricultural use. Land is subdivided within families, meaning that farm size is reducing and an average farm is only $15,000 \mathrm{~m}^{2}$ in area [22], with an average of a quarter of an acre allocated for arable farming throughout the Sub County and almost all farmers engage largely in subsistence and minimal commercial production. The acreage under cash crops in Kisii Central Sub County is approximately 3,800ha while the area under food crops is about 12,500ha [23]. Livestock production is dominated by dairy and local poultry. Agriculture employs an estimated $80 \%$ of the population either directly or indirectly and the estimated rural poverty is $30 \%$ with some areas having as high as $61 \%$ according to Kisii county profile [23]. 


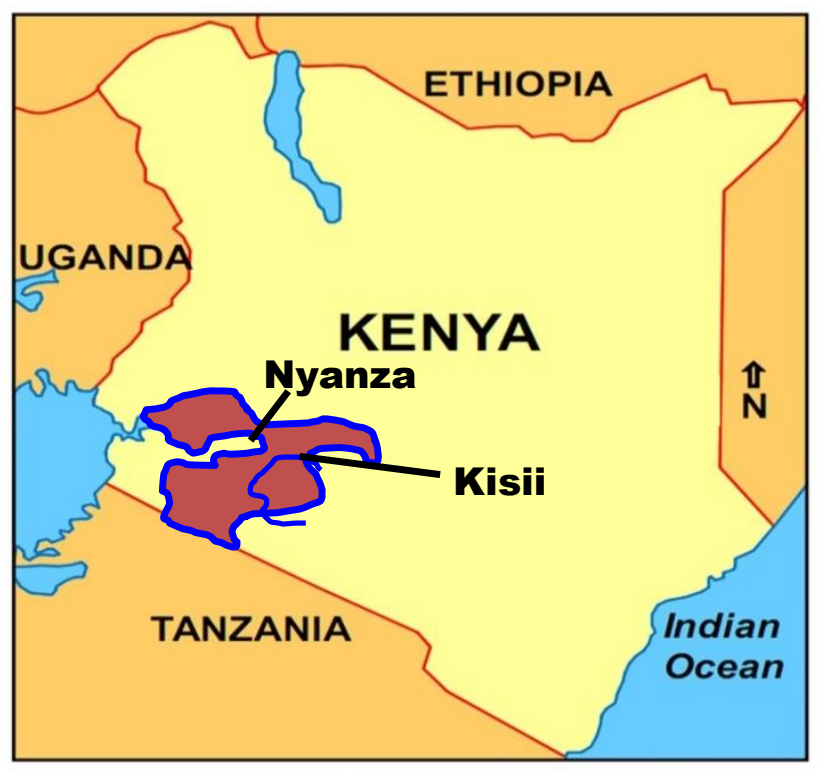

Figure 2.1: Kisii County, Nyanza Province of Kenya, where the research was undertaken

Source: Adopted from Google maps (20/4/2017)

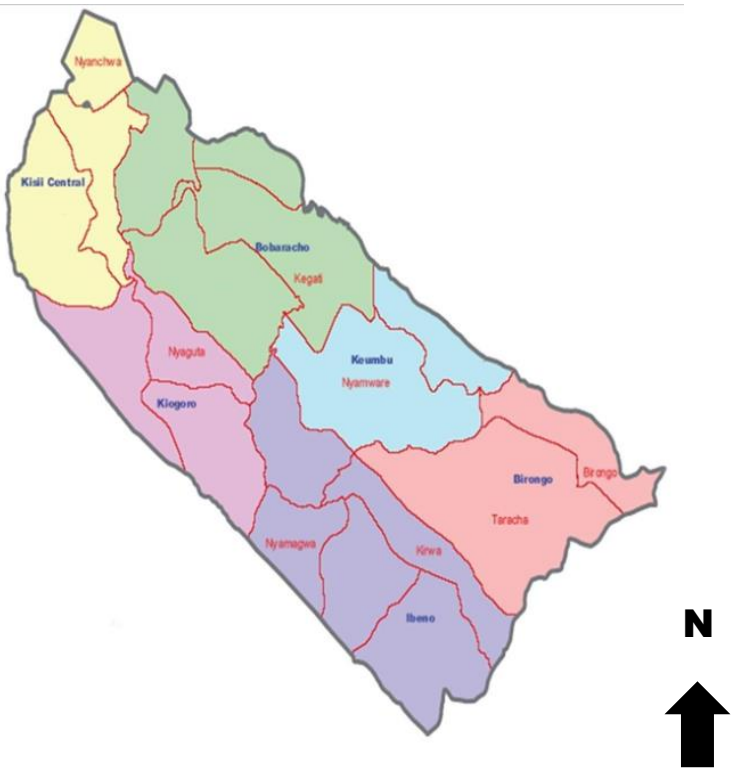

Figure 2.2: Kisii Sub-County Regions in Kisii County where the research was done

Source: Kisii county profile plan (20/4/2017)

\subsection{Data collection}

Eight administrative sub-locations were randomly selected in the sub-county. Ten farms were then selected at an equal $50 \mathrm{~m}$ distance along a $150 \mathrm{~m}$ transect laid across each sub-location in the study area. Soil samples were collected from each of the farms; a sub-sample was taken from a composite sample of ten soil cores of $5 \mathrm{~cm}$ diameter and $15 \mathrm{~cm}$ deep and put in germination trays in a greenhouse for weed seed bank assessment. Weed emergency was monitored after a week and later on weekly basis for three months. The number of seeds was estimated by counting the seedlings after germination. Diversity in the seed bank was calculated. Botanical identification of weed species was done by analysis of vegetative and reproductive parts in reference to guide books and comparing the weeds with voucher specimen deposited at National Museums of Kenya. Plant taxonomists were consulted to help identify weed species that could not be identified in the field.

\section{Data Analysis}

Assessment of phytosociological structure was done using absolute and relative values of density, frequency, abundance and importance value for each weed species [8]. The following parameters were computed;

Absolute frequency $=$ number of sampling units with species present/total number of sampling units.

Relative frequency $=$ species absolute frequency/sum of all absolute frequencies $\mathrm{x} 100$.

Weed species diversity was evaluated using Shannon Index $\left(H^{\prime}\right)$ based on natural logarithm which considers equal weight between abundant and rare weed species. Higher values of the diversity index obtained will imply greater weed species diversity [28]; Shannon Index $\left(H^{\prime}\right)=\sum \mathrm{p}_{i}$ $\left(\operatorname{lnp}_{i}\right)$

Where, $H^{\prime}=$ diversity

$\sum=$ Summation,

$\mathrm{p}_{i}=\mathrm{n}_{i} \mathrm{~N}_{\text {total, }}$

ln = natural logarithim,

$\mathrm{n}_{i}=$ number of individuals of species $i$

$\mathrm{N}_{\text {total }}=$ Total number of individuals on all species 
Data on weed management practices and number of weeds in the farms was subjected to analysis of variance using Genstat, Release15.1. Mean separation was accomplished using Fisher's protected Least Significant Difference. The relation between weed management practises and soil weed seed bank was determined based on the effect of weed management practises on mean number of weeds in soil weed seed bank reserves. General analysis of variance (ANOVA) was used to compare the effect on mean number of weed species.

\section{Results}

\subsection{Weed management practises and soil weed seedbank}

The weed management practises recorded in the respective farms were tallied with the number of weed species obtained from the soil weed seedbank. Cover cropping, mulching and organic farming had 3 weed species, hoeing and mechanical tillage recorded 4 weed species, livestock grazing/browse and slashing had 3 weed species while crop rotation and use of herbicides recorded 2 weed species as shown in Table 4.1.

Table 4.1: Categories of weed management practises and number of weed species recorded in soil weed seedbank

\begin{tabular}{llc}
\hline Serial No. & Weed management practises & $\begin{array}{c}\text { Number of weed } \\
\text { species on weed soil } \\
\text { seed bank }\end{array}$ \\
\hline $\mathbf{1}$ & Cover cropping, mulching and organic farming. & 3 \\
$\mathbf{2}$ & Crop rotation and use of herbicides. & 2 \\
$\mathbf{3}$ & Hoeing and Mechanical tillage. & 4 \\
$\mathbf{4}$ & Livestock graze/Browse, Slashing and Hand pulling. & 3
\end{tabular}

Totals

12

Hoeing and mechanical tillage recorded the highest number of weed species on soil weed seedbank of 4 weed species and was closely followed by cover cropping, mulching and organic farming and livestock grazing/browse and slashing which had 3 weed species respectively while crop rotation and use of herbicides recorded 2 weed species as shown in Figure 4.1.

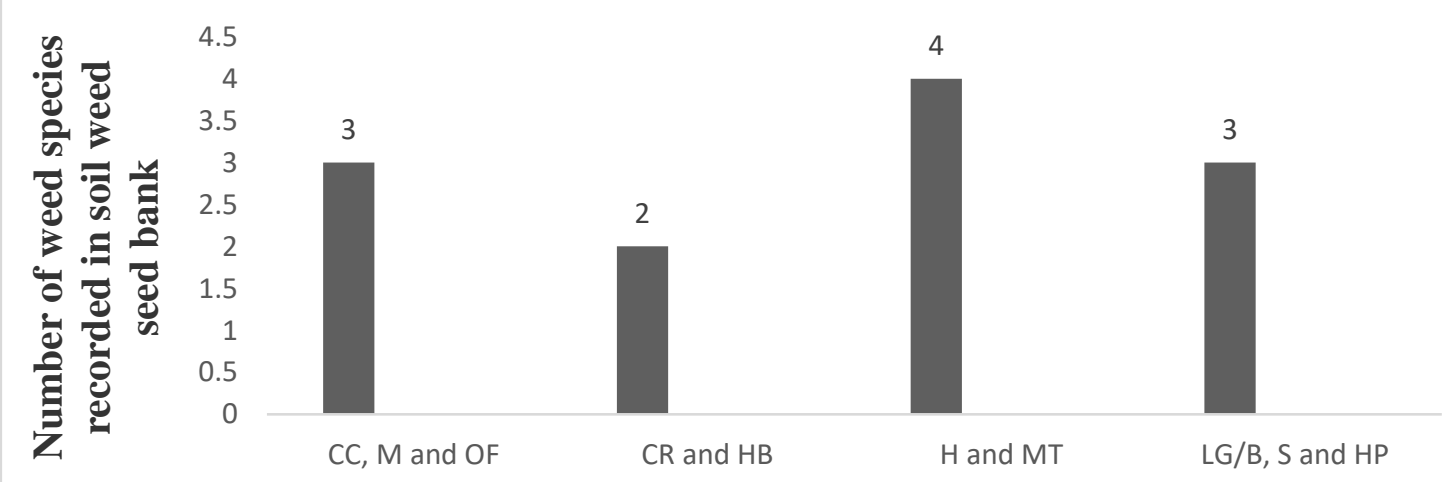

Combination of weed management practises

Figure 4.1: Combination of weed management methods and number of weed species recorded in soil weed seed bank

Key; CC- Cover cropping, M- Mulching, OF- Organic farming, CR- Crop rotation, HB- Herbicides, H- Hoeing, MT- Mechanical tillage, HP- Hand pulling, LG/B- Livestock graze/ Browse, S- Slashing 
A comparison between number of weed species and weed management practises both on farms and soil weed seed bank was done. Hoeing recorded the highest weed species both on farms and in soil weed seedbank of 9 and 4 respectively as illustrated in Figure 4.2
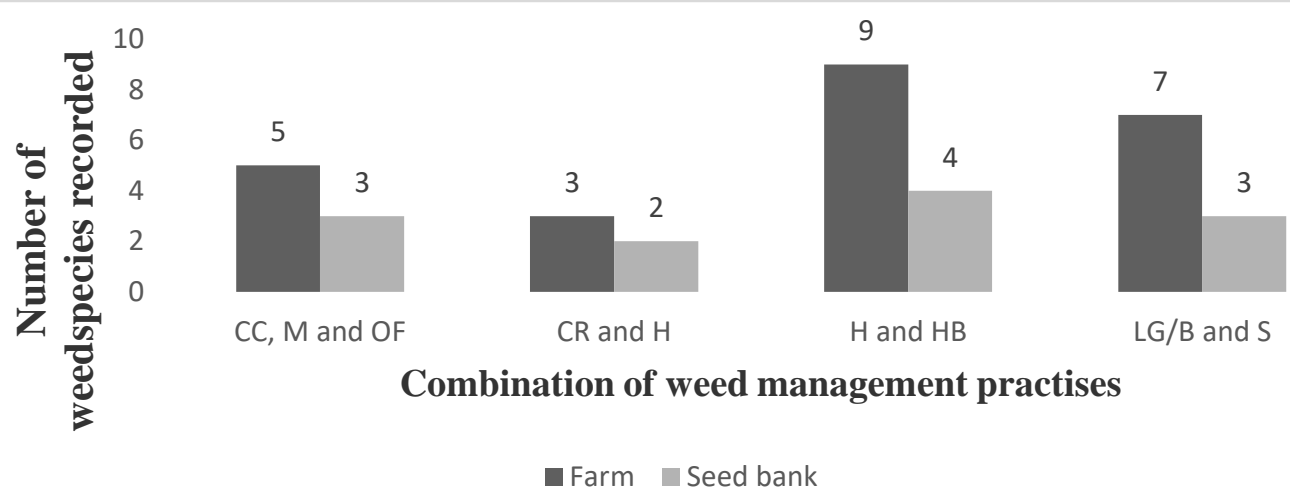

Figure 4.2: Comparison between numbers of weed species obtained from farms and in soil weed seed bank with the different categories of weed management methods

Key; CC- Cover cropping, M- Mulching, OF- Organic farming, CR, Crop rotation, H- Hoeing, MT- Mechanical tillage, HP- Hand pulling, LG/B- Livestock graze/ Browse, S- Slashing

\subsection{Diversity index of weed species in soil weed seedbank}

\subsubsection{Weed species diversity index in soil weed seedbank in each sampled farm}

In each of the sampled farms, computation of soil weed seedbank diversity index based on Shannon formula was done. Farm 33, 14 and 20 had the highest diversity index of 1.94, 1.76 and 1.74 respectively while farm 44 and 79 , each had the lowest diversity index of 0.14 as shown in Table 4.2. Variation of weed diversity index across the sampled farms was noted and this might be attributed to the differences in management practises and adaptive features among individual weed species.

Table 4.2: Weed species diversity index in soil weed seedbank in each of the surveyed farms

\begin{tabular}{llllllll}
\hline Farm & $\begin{array}{c}\text { Weed species } \\
\text { Diversity } \\
\text { Index }\end{array}$ & Farm & $\begin{array}{c}\text { Weed species } \\
\text { Diversity } \\
\text { Index }\end{array}$ & Farm & $\begin{array}{c}\text { Weed } \\
\text { species } \\
\text { Diversity } \\
\text { Index }\end{array}$ & Farm & $\begin{array}{c}\text { Weed species } \\
\text { Diversity } \\
\text { Index }\end{array}$ \\
\hline & 0.9322 & $\mathbf{2 1}$ & 1.2995 & $\mathbf{4 1}$ & 1.2210 & $\mathbf{6 1}$ & 1.1646 \\
$\mathbf{2}$ & 1.4533 & $\mathbf{2 2}$ & 1.0139 & $\mathbf{4 2}$ & 1.0877 & $\mathbf{6 2}$ & 0.7563 \\
$\mathbf{3}$ & 1.2481 & $\mathbf{2 3}$ & 0.9296 & $\mathbf{4 3}$ & 1.1823 & $\mathbf{6 3}$ & 0.0914 \\
$\mathbf{4}$ & 1.3939 & $\mathbf{2 4}$ & 0.3018 & $\mathbf{4 4}$ & 0.1357 & $\mathbf{6 4}$ & 0.8647 \\
$\mathbf{5}$ & 1.0920 & $\mathbf{2 5}$ & 1.4767 & $\mathbf{4 5}$ & 0.3379 & $\mathbf{6 5}$ & 0.7651 \\
$\mathbf{6}$ & 1.4707 & $\mathbf{2 6}$ & 0.9232 & $\mathbf{4 6}$ & 1.2912 & $\mathbf{6 6}$ & 0.8903 \\
$\mathbf{7}$ & 0.5364 & $\mathbf{2 7}$ & 1.2511 & $\mathbf{4 7}$ & 0.3284 & $\mathbf{6 7}$ & 0.8883 \\
$\mathbf{8}$ & 1.1008 & $\mathbf{2 8}$ & 1.4978 & $\mathbf{4 8}$ & 0.3676 & $\mathbf{6 8}$ & 0.7665 \\
$\mathbf{9}$ & 1.1753 & $\mathbf{2 9}$ & 0.9505 & $\mathbf{4 9}$ & 0.3117 & $\mathbf{6 9}$ & 0.9468 \\
$\mathbf{1 0}$ & 0.9743 & $\mathbf{3 0}$ & 1.2059 & $\mathbf{5 0}$ & 1.2633 & $\mathbf{7 0}$ & 1.1268 \\
$\mathbf{1 1}$ & 1.2758 & $\mathbf{3 1}$ & 0.1869 & $\mathbf{5 1}$ & 1.2136 & $\mathbf{7 1}$ & 0.3962 \\
$\mathbf{1 2}$ & 0.4374 & $\mathbf{3 2}$ & 1.0705 & $\mathbf{5 2}$ & 1.1545 & $\mathbf{7 2}$ & 1.4847 \\
$\mathbf{1 3}$ & 1.6085 & $\mathbf{3 3}$ & 1.9449 & $\mathbf{5 3}$ & 1.1052 & $\mathbf{7 3}$ & 1.3631 \\
$\mathbf{1 4}$ & 1.7663 & $\mathbf{3 4}$ & 0.8897 & $\mathbf{5 4}$ & 1.1745 & $\mathbf{7 4}$ & 0.1906 \\
$\mathbf{1 5}$ & 0.6851 & $\mathbf{3 5}$ & 0.8897 & $\mathbf{5 5}$ & 1.3729 & $\mathbf{7 5}$ & 1.0941 \\
$\mathbf{1 6}$ & 1.5496 & $\mathbf{3 6}$ & 0.9407 & $\mathbf{5 6}$ & 0.4427 & $\mathbf{7 6}$ & 0.1530 \\
$\mathbf{1 7}$ & 1.4098 & $\mathbf{3 7}$ & 0.8599 & $\mathbf{5 7}$ & 0.1743 & $\mathbf{7 7}$ & 1.2677 \\
$\mathbf{1 8}$ & 1.5683 & $\mathbf{3 8}$ & 0.9259 & $\mathbf{5 8}$ & 1.2610 & $\mathbf{7 8}$ & 1.3926 \\
$\mathbf{1 9}$ & 1.2033 & $\mathbf{3 9}$ & 0.7998 & $\mathbf{5 9}$ & 1.0237 & $\mathbf{7 9}$ & 0.1448 \\
$\mathbf{2 0}$ & 1.7426 & $\mathbf{4 0}$ & 0.7381 & $\mathbf{6 0}$ & 1.2582 & $\mathbf{8 0}$ & 1.0367 \\
\hline
\end{tabular}




\subsubsection{Weed species diversity index in soil weed seedbank on farms in each sampled sub- location}

Weed species diversity index on farms of the sampled administrative sub-locations was calculated and the findings are as shown in Table 4.3. Nyanchwa recorded the highest diversity index followed by Kirwa, Nyamware and Nyaguta with 1.525, 1.2181 .152 and 1.140 weed species diversity index respectively while Taracha recorded the least weed species diversity index of 0.926 . Weed species diversity was higher in relatively low and medium altitude zones and weed diversity increased in farms with hoeing and hand pulling weed management practises. The widespread of weed species found in most altitudes can also be attributed to their best adaptability in different edaphic, prevailing environmental conditions and resistance to management practises.

Table 4.3: Weed species diversity index in soil weed seedbank on farms in each sampled sublocation

\begin{tabular}{llc}
\hline Location & Sub-location & Weed species diversity index $\left(\mathbf{H}^{\prime}\right)$ \\
\hline Kisii Central & Nyaguta & 1.14027 \\
Kiogoro & Nyanchwa & 1.52467 \\
Bobaracho & Kegati & 1.18500 \\
Ibeno & Nyamagwa & 1.02461 \\
Keumbu & Nyamware & 1.15268 \\
Ibeno & Kirwa & 1.21806 \\
Birongo & Taracha & 0.92608 \\
& Birongo & 1.25235
\end{tabular}

Nyanchwa recorded the highest diversity index (1.52) followed by Kirwa (1.218), Nyamware (1.152) and Nyaguta with 1.140 weed species diversity index while Taracha ranked last with weed species diversity index of 0.926 as indicated in Figure 4.3.

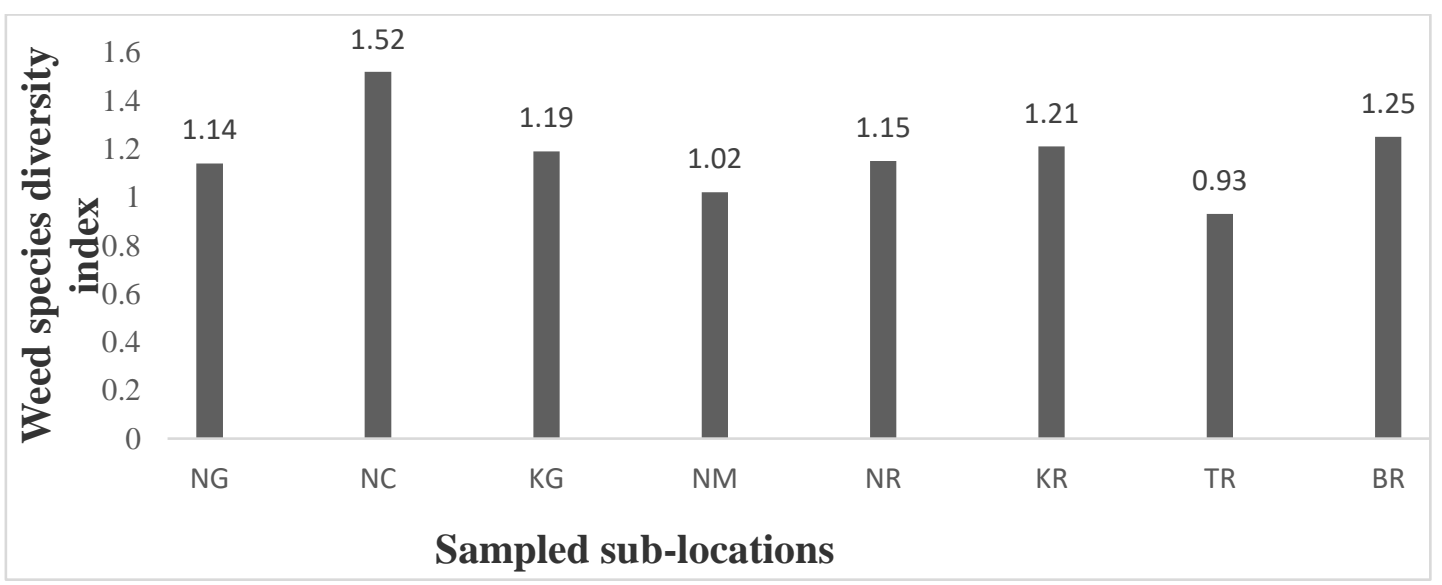

Figure 4.3: Weed species diversity index in soil weed seed bank on farms in each sampled administrative sub-location

Key: Nyaguta- NG, Nyanchwa- NC, Kegati- KG, Nyamagwa- NM, Nyamware- NR, Kirwa- KR, Taracha-TR, Birongo- BR

\subsubsection{Overall weed species diversity index in the surveyed farms in soil weed seedbank}

The total number of all individual weed species collected from the soil weed seed bank was determined. The overall diversity index of the weed species in the soil weed seed bank from the surveyed farms was calculated using Shannon index and tabulated as shown in Table 4.4. Weed species diversity was relatively lower than that recorded on farms and this can be linked to weed management practises that contributed to decrease in weed soil seed bank because they limit new seed deposition to the bank and also hinder seed germination from taking place through mechanisms such as seed rains. 
Table 4.4: Overall diversity index of weed species in soil weed seedbank

\begin{tabular}{lcccc}
\hline Weed species & $\begin{array}{c}\text { No. of } \\
\text { sample }\end{array}$ & pi=sample/sum & $\ln (\mathbf{p i})$ & pi* $\mathbf{n}(\mathbf{p i})$ \\
\hline Galinsoga parviflora & 1239 & 0.50 & -0.69 & -0.345 \\
Amaranthus hybridus & 123 & 0.05 & -2.99 & -0.150 \\
Bidens pilosa & 5 & 0.002 & -6.21 & -0.012 \\
Digitaria scaralum & 710 & 0.29 & -1.23 & -0.357 \\
Cyperus esculentus & 211 & 0.09 & -2.53 & -0.228 \\
Oxalis latifolia & 51 & 0.02 & -3.91 & -0.078 \\
Nicandra physalodes & 47 & 0.02 & -3.91 & -0.078 \\
Commelina benghalensis & 42 & 0.02 & -3.91 & -0.078 \\
Tagetes minuta & 2 & 0.0008 & -7.13 & -0.006 \\
Portulaca oleracea & 65 & 0.03 & -3.51 & -0.105 \\
Chenopodium opulifolium & 20 & 0.008 & -4.83 & -0.039 \\
Gynandropsis gynandra & 1 & 0.0004 & -7.82 & -0.003 \\
Sum= 2,516 & & & & Sum=-1.479 \\
\hline
\end{tabular}

Therefore, $\boldsymbol{H}^{\prime}=1.48$

4.3 Relation between weed species in soil weed seed bank and management practises

4.3.1 Weed species in soil weed seedbank

A total of 2,516 individual weeds belonging to nine families of 12 genera and 12 weed species were recorded. The family Asteraceae had the highest number of species richness (3) followed by Amaranthaceae family with 2 species while the remaining families had one species each (Table 4.5)

Table 4.5: Families, genera and species names of weed species in soil weed seed bank

\begin{tabular}{|c|c|c|c|c|c|}
\hline \multicolumn{2}{|c|}{ Family } & Genus name & Species name & $\begin{array}{l}\text { Absolute } \\
\text { Frequency }\end{array}$ & $\begin{array}{l}\text { Relative } \\
\text { frequency }(\%)\end{array}$ \\
\hline \multicolumn{2}{|c|}{1 Poaceae } & Digitaria & D. scalarum & 710 & 28.6 \\
\hline \multirow{6}{*}{\multicolumn{2}{|c|}{2 Asteraceae }} & Bidens & B. pilosa & 5 & 0.20 \\
\hline & & Tagetes & T. minuta & 21 & 0.85 \\
\hline & & Galinsoga & G. parviflora & 1239 & 51.9 \\
\hline & & Commelina & C. benghalensis & 42 & 1.7 \\
\hline & & Nicandra & N. physalodes & 47 & 1.9 \\
\hline & & Amaranthus & A. hybridus & 123 & 4.8 \\
\hline 3 & Commelinaceae & Chenopodium & C. opulifolium & 21 & 0.9 \\
\hline 4 & Solanaceae & Gynandropsis & G. gynandra & 1 & 0.4 \\
\hline 5 & Amaranthaceae & Oxalis & O. latifolia & 51 & 2.1 \\
\hline 6 & Capparaceae & Cyperus & C. esculentus & 211 & 8.5 \\
\hline 7 & Oxalidaceae & Portulaca & P. oleracea & 64 & 2.6 \\
\hline 8 & Cyperaceae & & & & \\
\hline 9 & Portulacaceae & & & & \\
\hline
\end{tabular}




\subsubsection{Comparison between weed species in farms and in soil weed seed bank}

Twenty four weed species were recorded on farms while the soil weed seedbank had twelve weed species. Relative frequency of weed species on farms and in soil weed seedbank was computed and comparison made. Weed species G. parviflora had the highest relative frequency both on farms and in soil weed seedbank. Weed species $P$. clandestinum, $C$. dactylon, and $C$. banariensis occurred only in the farms and not in soil weed seedbank while others like $C$. opulifolium and P. oleracea occurred only in soil weed seedbank (Table 4.6).

Table 4.6: Comparison between relative frequencies of weed species on farms and in soil weed seedbank

\begin{tabular}{ccc}
\hline Weed species & Farm & Soil weed seedbank \\
Relative frequency $(\%)$
\end{tabular}

\begin{tabular}{lcc}
\hline Pennisetum clandestinum & 8.52 & - \\
Bidens pilosa & 7.96 & 0.20 \\
Digitaria scalarum & 7.85 & 28.6 \\
Commelina benghalensis & 4.37 & 1.7 \\
Tagetes minuta & 6.73 & 0.85 \\
Galinsoga parviflora & 9.30 & 51.9 \\
Nicandra physalodes & 2.69 & 1.9 \\
Amaranthus hybridus & 5.72 & 4.8 \\
Cynodon dactylon & 8.18 & - \\
Solanum nigrum & 1.35 & - \\
Gynandropsis gynandra & 0.67 & 0.4 \\
Oxalis latifolia & 4.26 & 2.1 \\
Conyza banariensis & 5.72 & - \\
Datura stramonium & 2.80 & - \\
Solanum incanum & 3.81 & - \\
Cyperus esculentus & 7.17 & 8.5 \\
Emilia brachycephala & 3.92 & - \\
Pteridium aquilinum & 0.67 & - \\
Crassocephalum vitellinum & 1.79 & - \\
Leonotis mollissima & 0.56 & - \\
Leonotis martinicensis & 0.56 & - \\
Physalis ixocarpa & 0.56 & - \\
Chenopodium opulifolium & - & 0.9 \\
Portulaca oleracea & - & 2.6 \\
\hline
\end{tabular}

\subsubsection{Relation between weed management practises and soil weed seedbank}

The relation between weed management practises and weed species in soil weed seed bank was determined based on the effect of weed management practises on weed species diversity in soil weed seed bank reserves. Weed management practises hoeing, cover cropping, mulching, and crop rotation had equal effect on soil wed seed bank index compared with other weed management practises. Means accompanied by different letter(s) are significantly different (Fisher's protected least significant difference test, $\mathrm{P} \leq 0.05$ ). [Appendix I(i)]. Weed management practises significantly affected soil weed seedbank diversity index $(\mathrm{P} \leq 0.05)$ and therefore, the index values were statistically different among samples from farms with different weed management practises. [Appendix I(ii)]. Therefore, the null hypothesis that there is no relationship between abundance and diversity of growing weeds and weed soil seed bank on farms in Kisii Central Sub County, Western Kenya is rejected. 


\section{Discussions}

\subsection{Weed management practises and soil weed seed bank}

In this study, the weed species abundance declines across the studied farms. Study results indicate that weed management practises contributed to decrease in weed soil seed bank because they limit new seed deposition to the bank and also hinder germination from taking place through mechanisms such as seed rains which concurs with observations made by [9]. In temperate regions, weed seed bank declines by $32 \%$ annually, [27] while in tropical regions, the soil weed seed bank is smaller and the decline tends to be rapid because, according to [9], though there is high seedling recruitment rate linked to conducive ecological conditions for seed germination which persist for longer periods than in temperate regions, there is high seed mortality due to high relative humidity and temperatures, predators, pathogens, seedling mortality due to seed germination in short, hot dry seasons that occur during the rainy season, a shorter duration or absence of seed dormancy of most weed species and other seeds having a low seed viability.

Additionally, this study shows that the soil weed seed bank tend to decrease due to management practises that hinder weed seed germination hence limiting new weed seed deposition into the soil weed seed bank. Therefore, if arable farms are not cultivated regularly for planting and situations where deposition of new weed seeds is low then the rate of reduction of weed seed bank will vary depending on ecological conditions [9].

\subsubsection{Weed species diversity in soil weed seedbank}

\subsubsection{Weed species diversity in soil weed seedbank in each surveyed farm}

Across the studied farms, there was variations in weed species diversity. The diversity of a weed species in the soil weed seed bank is related not only to weed management factors and crop history but also to reproductive capacity of the weed species [18]. These findings are in agreement with those of [13] who noted that possible causes in the decline of the amount weed species in soil weed seed bank may be due to various factors such as seed and seedling losses in the field due to activities of microorganisms, insects, birds, rodents, lizards and other animals which in turn leads to variations in soil weed seed bank.

\subsubsection{Weed species diversity in soil weed seedbank in each sampled sub-location}

Weed diversity varied across the sampled sub-locations and this might be due to the differences in growth, production of high number of seeds, dormant seeds, excellent seed dispersal mechanisms, high competitive ability among individual weed species. Weed species diversity was higher in relatively low and medium altitude zones and weed diversity increased in farms with adoption of inefficient and ineffective weed control practises. The widespread of weed species found in most altitudes can also be attributed to their best adaptability in different edaphic, prevailing environmental conditions and resistance to management pressures. Similar study conducted by [31] in wheat fields of district Rahim Yar Khan, Pakistan reflected same results.

\subsubsection{Overall weed species diversity in soil weed seedbank}

The Shannon index increases as abundance of a community increases. The higher values of $H^{\prime}$ indicate greater floristic diversity [28].

Weed species diversity was calculated and recorded a diversity index of $H^{\prime}=1.48$ for weed species in the soil weed seed bank which was lower than 2.66 obtained by [1] who carried out a similar study in Southern Brazil. The higher values of $H^{\prime}$ obtained usually will indicate greater floristic diversity [28] and therefore, weed species found in the farms had diversity index $\left(H^{\prime}\right)=$ 2.77 and indicates a high floristic diversity than in soil weed seed bank. Species of the family Asteraceae largely dominated in the weed soil seed bank as evaluated. However, studies carried out in other tropical regions by [14] observed that $86 \%$ of species found in the soil weed seed bank of 22 rice fields in Cambodia were of Cyperaceae family. In another related study conducted in Nepal, [5] reported that $37 \%$ of the grasses and sedges contributed to the soil weed seed bank. Generally, the dominance of a weed species in the soil weed seed bank can be related to cultural weed management practises, weed species history and also the reproductive capacity. 
These results depicts that weed seed bank reserve at this study area might drastically decreased since management practices prevent new seed deposition into soil weed seed bank through mechanisms such as seed rains. These findings are in agreement with those obtained by [30] that the traditional weed management practises farmers employ in their farms like hand weeding, hoeing contribute to high weed diversity, persistence and ever re-occuring in the farms since they are ineffective and untimely carried out.

\subsection{Relation between weed species in soil weed seed bank and management practises}

\subsubsection{Weed species in soil weed seedbank}

The five most dominant and widespread weed species within the soil weed seedbank in the study area were G. parviflora, D. scalarum, C. esculentus, A. hybridus, and P. oleraceae while the rest of the other weed species were infrequent. Species of the family Asteraceae largely dominated in the soil weed seed bank as evaluated. However, studies carried out in other tropical regions by [14] observed that $86 \%$ of species found in the weed seed banks of 22 rice fields in Cambodia were of Cyperaceae family.

\subsubsection{Comparison between weed species on farms and in soil weed seed bank}

On the studied farms, twenty four weed species from twenty two genera belonging to ten families were observed with Asteraceae being the most abundant family while in soil weed seedbank, nine families of 12 genera and 12 weed species were recorded. The family Asteraceae was still dominant in the soil weed seedbank. In farms, $P$. clandestinum and $C$. dactylon dominated with a relatively higher frequency though they did not occur in soil seed bank. G. parviflora highly dominated both in soil weed seed bank and in farms. Though farms recorded higher number of weed species than in soil weed seed bank, weed seeds are usually prone to possible predation and also subjected to periods of water shortages. Possible differences observed between the amount weed species in farms and in soil weed seedbank may be explained by various factors like seed and seedling losses in the field due to activities of microorganisms, insects, birds, rodents, lizards and other animals. [10], carried out a similar study in organic cereal fields in Netherlands and observed that weed seed losses due to predators range between 5-15\%. Similarly, the weed seed losses may be due to occassional periods of soil water stress and germination failure [13]. The dominance of a weed species in the soil weed seed bank is related not only to cultural factors and crop history but also to reproductive capacity of the weed species [18]. [32], carried out a similar study on soil weed seed banks in natural fields and observed that soil moisture content was one of the most vital abiotic factor that affects vegetation patterns in a given area. The weed species with higher relative frequency values occurred in relatively all farms. Weeds such as $G$. parviflora and $D$. scalarum have well adaptive features like excellent modes of seed dispersal and tolerance to human and environmental pressure thus persist and dominate in arable farms. In related studies done by [33] on different weed control methods in coffee in Kenya, observed that G. parviflora, C. dactylon and B. pilosa were the most frequent weed species compared to the rest of other weed species. [34]) conducted a similar study and reported that weed species with high percentage of frequency might exert competitive and allelopathic stress to reduce growth and yield of associated crop. These weed flora composition has a negative impact of lowering crop yield quantity and quality. In this study therefore, the results indicate that the weed seed bank is lower than weed species on farms due to limited weed seed deposition into this bank.

\subsubsection{Weed management practises and soil weed seedbank}

This study results depicts that soil weed seed bank reserve in this study area might have drastically decreased since the diversity index value $H^{\prime}$ of 1.48 is lower than 2.77 obtained on farms which implies that management practises prevent new seed deposition into the soil weed seed bank through mechanisms such as seed rains. Further still, these results shows that the weed management practises employed by most farmers hinder weed seed germination hence limiting new weed seed deposition into the soil weed seed bank. Similarly, if arable farms are not cultivated regularly for planting and situations where deposition of new weed seeds is low then the rate of reduction of weed seed bank will vary depending on ecological conditions [9]. In agreement with these findings, 
[30] observes that weed management practises adopted by most farmers in their farms like hoeing, mulching and cover cropping contribute to high weed diversity, persistence and ever re-occuring in the farms since they are ineffective and untimely carried out.

\subsubsection{Relation between weed management practises and soil weed seedbank}

Results of this study shows that the soil weed seed bank tend to vary due to weed management practises that hinder weed seed germination hence limiting new weed seed deposition into the soil weed seed bank. From the results obtained, weed management practises especially mechanical tillage, livestock grazing/browse and organic farming had significantly $(\mathrm{p} \leq 0.05)$ higher effect in increasing soil weed seedbank. Livestock grazing or browsing on weeds or weed-infested crops can destroy the viability of weed seeds. However, some seeds pass through livestock digestive system unharmed and can germinate if spread back onto the farms. Hoeing, crop rotation and hand pulling significantly $(\mathrm{p} \leq 0.05)$ reduced weed seed reserves; were observed to have a negative effect on number of weed species in soil weed seedbank. In related studies, [3] observed that mechanical weed management practises such as hand-pulling, hoeing, slashing, and tillage destroy weeds or make the environment less favorable for seed germination and weed survival thus reducing weed seed reserves.

In similar a study conducted by [26] observed that cutting of mature weed plants before the spread their seeds proves to be an effective preventive measure in weed control thus reduction in weed seed reserves. Cultural weed management practises such as mulching, crop rotation and cover cropping leads to suppression of weeds in arable farms. Cover crops are known to prevent the development of weed population through smothering and suppression of weed growth and development and therefore should be incorporated in a cropping system [16].

Adoption of tillage operations and application of non-selective herbicides produces weed-free fields for planting and reduces weed seed deposition into soil weed seedbank [7]. Therefore, it is observed that if arable farms are not cultivated regularly for planting and situations where deposition of new weed seeds is low then the rate of reduction of weed seed bank will vary depending on the prevailing ecological conditions [9].

\section{Conclusion}

The soil weed seed bank tend to vary depending on weed management practises employed by farmers that affect weed seed germination hence limiting new weed seed deposition into the soil weed seed bank. The number of weed species recorded in soil weed seed bank on farms with hoeing, crop rotation and hand-pulling was significantly different from those obtained from farms with mechanical tillage, livestock grazing/browse and organic farming weed management practises.

\section{Recommendations}

- Farmers to be exposed to agricultural experts who will train them on weed management practises. Effective land preparation, mulching, cover-cropping and crop rotation should be adopted by farmers to reduce rates of weed invasion to maximise crop yields. However, farmers should adopt the integrated weed management (IWM) technique which is a holistic approach to weed management that integrates different methods of weed control to provide the crop with an advantage over weeds.

- Farmers to be encouraged to continue studying weeds, their damage and control and have weed cultural knowledge which should be passed to the next generations.

\section{Conflict of Interest}

"The author(s) declare(s) that there is no conflict of interest."

There was no role of the funding sponsors in the design of the study; in the collection, analyses or interpretation of data; in the writing of the manuscript, or in the decision to publish the results. 


\section{Acknowledgement}

The author would like to acknowledge the input, support and guidance accorded by the project study supervisors, the botany department of Jomo Kenyatta University of Agriculture and Technology, all the farm managers and management staff of the surveyed farms, the survey biometricians, the librarians at the museums of Kenya, Mr. Wanjohi, P. K. (University of Eldoret) and botany departments (Kisii University).

\section{Appendix I: Data Analysis Output}

(i): Weed management practises on soil weed seedbank diversity

Variate: Diversity index

\begin{tabular}{|l|l|l|l|l|c|}
\hline \multicolumn{1}{|c|}{$\begin{array}{c}\text { Source of } \\
\text { variation }\end{array}$} & \multicolumn{1}{|c|}{ d.f. } & \multicolumn{1}{c|}{ s.s. } & m.s. & F & Sig. \\
\hline Weedmgt & 31 & 7.8454 & 0.2531 & 1.75 & 0.039 \\
\hline Residual & 48 & 6.9324 & 0.1444 & & \\
\hline Total & 79 & 14.7778 & & & \\
\hline
\end{tabular}

(ii): Fisher's protected least significant difference test

Weed management

Cover cropping and organic farming

Livestock grazing and slashing

Mulching and organic farming

Hoeing and mulching

Mulching and slashing

Hoeing and slashing

Cover cropping and slashing

Hoeing and hand pulling

Mechanical tillage and livestock grazing

Crop rotation and livestock grazing

Crop rotation and mechanical tillage

Hand pulling and cover cropping

Herbicides and mechanical tillage

Hoeing and livestock grazing

Mulching and mechanical tillage

Hoeing and crop rotation

Cover cropping and livestock grazing

Crop rotation and cover cropping

Hoeing and livestock grazing

Hoeing and herbicides

Hand pulling and herbicides

Hoeing and mechanical tillage

Crop rotation and use of herbicides

Crop rotation and slashing

Hoeing and cover cropping

Slashing and use of herbicides

Mulching and hand pulling

Mechanical tillage and organic farming

Hoeing and organic farming

Mechanical tillage and slashing

Crop rotation and organic farming

Cover cropping and mechanical tillage
Mean

$0.153 \mathrm{a}$

$0.191 \mathrm{ab}$

$0.396 \mathrm{abc}$

$0.547 \mathrm{abcd}$

$0.629 \mathrm{abcde}$

0.656 abcde

$0.766 \mathrm{abcdef}$

$0.805 \mathrm{abcdef}$

0.890abcdef

0.890abcdef

0.906abcdef

0.951 abcdef

1.068abcdef

1.101 abcdef

1.105abcdef

$1.134 \mathrm{cef}$

1.155abcdef

$1.155 \mathrm{cef}$

$1.157 \mathrm{cef}$

1.206abcdef

$1.248 \mathrm{bcdef}$

$1.251 \mathrm{bcdef}$

$1.263 \mathrm{bcdef}$

$1.300 \mathrm{cdef}$

$1.317 \mathrm{f}$

$1.363 \mathrm{cef}$

$1.386 \mathrm{ef}$

$1.394 \mathrm{cef}$

$1.405 \mathrm{f}$

$1.485 \mathrm{ef}$

$1.550 \mathrm{ef}$

$1.685 \mathrm{f}$ 


\section{References}

[1] M.V.M. Andrade et al., (2009). Levantamento florístico e estrutura fitossociológica do estrato herbáceo e subarbustivo em áreas de caatinga no Cariri paraibano. Revista Caatinga, v. 22, n. 1, p. 229-237.

[2] L. Bastiaans et al., (2008) Focus on ecological weed management.

[3] H. J. Beckie (2007). Beneficial management practices to combat herbicide-resistant grass weeds in the Northern Great Plains. Weed Technol. 21:290-299.

[4] R. L. Benech-Arnold et al., (2000). Environmental control of dormancy in weed seed Banks in soil. Field Crops Research, 60: 105-122.

[5] M. D. Bhatt and S.P. Singh (2007) Soil weed seed bank dynamics of weed flora in upland and Low land rice paddy cultivation areas of far western Nepal. Scientific World. 5: 54-59.

[6] A. Davis et al., (2005) Integrated weed management, “One year's seeding”.Extension Bulletin E-2931.East Lansing, MI. Michigan University.

[7] M. N. Dogan et al., (2009): Effect of presowing and pre-emergence glyphosate applications on weeds in stale seedbed cotton. Crop Prot. 28, 503-507.

[8] M. D. Dombois and H. Ellenberg (1974). Aims and methods in vegetation ecology. John Wiley and Sons, New York. Reprint (2003) Blackburn Press, ISBN 1-930665-73-3.

[9] M. A. Garcia (1995). Relationship between weed community and soil seed bank in a tropical agro- ecosystem. Agriculture, Ecosystem and Environment 55:139-147.

[10] C.M. Ghersa and W. Martinez (2000). Ecological correlates of weed size and persistence In the soil under different tilling systems. Implication for weed management. Field Crop Research, vol. 67, no. 2, p. 141-148.

[11] K.Z. Harbuck (2007) Weed seed bank dynamics and composition of Northern Great Plain's cropping systems. Montana State University, MS. Thesis.

[12] International rice research institute, (2010). Rice knowledge bank. Makati: Irri.

[13] R. A. Isaac et al., (2008) Banco de Sementes e flora emergentes de planta daninhas. Planta Daninha, vol. 26, no. 3. p. 521-530.

[14] A. Kamoshita et al., (2010) Ecophysiological study on weed seed bank and weeds in Cambodian paddy fields with contrasting water availability. Weed Biology and Management, vol. 10, no. 4, pp. 261-272.

[15] Kenya National Bureau of Statistics, (2009) Kenya population and Housing Census.

[16] H. M. Kruidhof et al., (2008). Ecological weed management by cover cropping: effects on weed growth in autumn and weed establishment in spring. Weed Res., 48 (2008), pp. 492 502.

[17] M. A. Leck and W. Schutz (2003) Regeneration of Cyperaceae with particular reference to seed ecology and seed banks. Perspectives in Plant Ecology, Evolution and systematics, vol. 7, no. 2, pp. 95-133.

[18] H. Lorenzi (2008) Plantas invasoras do Brasil: Terrestres aquáticas, parasitas e tóxicas. $4^{\text {th }}$ ed. Nova Odessa, Instituto Plantarum.

[19] K. Mace et al., (2007) Time scales as a factor in decision-making by French farmers on weed management in annual crops, Agric. Syst. 93, 115-142.

[20] S. Mahmoodi and A. Rahimi (2009) Estimation of critical period of weed control in corn in Iran, Weed acad. Sc., 49:67-72. 
[21] H. Mirza (2015) Crop-Weed Competition. Department of Agron, Sher -e-Bangla Agricultural University.

[22] MoA (Ministry of Agriculture), (2009) Farm Management Handbook of Kenya Vol. II Natural Conditions and Farm Management Information. 2nd Edition, Part a West Kenya Subpart A2 Nyanza Province, MoA Kenya in Cooperation with GTZ. Ministry of Agriculture, Nairobi.

[23] MoA (Ministry of Agriculture), (2012) Annual Work Plan: Kisii County. Ministry of Agriculture, Nairobi.

[24] J. Norsworthy and M. Oliveira (2006). Sicklepod (Senna obtusifolia) and emergency as affected by environmental factors and seedling depth. Weed sci., vol. 54 no.5 pp. 903-909.

[25] P. Oudhia. (2004) Phyto-sociological studies of rainy wasteland, pp. 40. In Liebman, C. L., Parker, V.T., and Fryer, S. L. (2004) Ecology of Soil Seed bank, Academic Press New York.pp.3-8.

[26] D. S. Riar et al., (2013) Adoption of best management practices for herbicide-resistant weeds in midsouthern United States in cotton, rice, and soybean. Weed Technol. 27(4), 788-797.

[27] H. A. Roberts and P. M. Feast (1973). Changes in the number of viable seeds in the soil under different regimes. Weed Research 13:298-303.

[28] C.E. Shannon and W. Weiner (1949) The mathematical theory of communication. Urbana University of Illinois Press

[29] E. Soltani et al., (2013). Seed bank modeling of volunteer oil seed rape: From seed fate in the soil to seedling emergence, 31: 267-279.

[30] P.V. Vissoh et al., (2004) Weeds as Agricultural constraints to farmers in Benin: Results of diagnostic study, NJAS, 52(3/4), pp.305-29.

[31] A. Waheed et al., (2009). Weed Community dynamics in wheat crop of District Rahim Yar Khan, Pakistan. Pakistan J. Botany, 59, 260-277.

[32] F. C. Maia et al., (2004). Soil seed bank variation patterns according to environmental factors in a natural grassland. Revista Brasileira de Sementes, 26, 126-137.

[33] J. K. Kimemia \& K. W. Nyabundi (1998). Difficult weeds in Kenya coffee. Kenya coffee Review, 63, 744- 49.

[34] S. Zaman et al., (2011). Floristic Composition, Communities and Ecological Characteristics of Weed of Wheat field, Pakistan. J. Botany, 43(6), 2817-2820. 